\title{
DOYNE LECTURE RESPONSES OF RETINAL AND CHOROIDAL VESSELS TO IONISING RADIATION
}

\author{
DESMOND B. ARCHER \\ Belfast
}

\section{HISTORICAL CONSIDERATIONS}

The discovery of X-rays by Roentgen in 1895 and radium by Curie, three years later, furnished the medical profession at the turn of the century with a novel diagnostic technique and therapeutic method of unparalleled versatility and power. Nevertheless, within a few years of the discovery of radiation, the initial enthusiasm of therapists was tempered by a growing catalogue of severe side

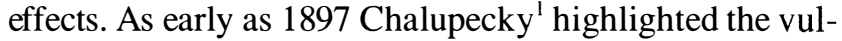
nerability of the cornea and conjunctiva to ionising radiation, and by 1908 Birch-Hirschfeld ${ }^{2}$ described the complication of radiation cataract. With further documentation of radiation-induced ocular injuries and better standardisation of radiation dose, it became clear that the various ocular tissues had different radiosensitivities. Rohrschneider ${ }^{3}$ in 1929 , by dint of careful observation and experimentation, was able to list the ocular structures in order of decreasing sensitivity: lens, conjunctiva, cornea, uvea, retina and optic nerve. Prevailing opinion held that the mature retina was essentially immune to clinical doses of radiation by virtue of its stable population of nerve cells and its 'cerebral-like' vasculature.

The first consistent reports of retinal vasculopathy following radiation were by Stallard and Moore, who were pioneering the treatment of retinoblastomas with radon seeds applied to the overlying sclera. ${ }^{46}$ They described the presence of retinal haemorrhage, exudation and pigmentation adjacent to the site of radiotherapy and noted that the visual prognosis was poor if the optic disc or macula were implicated. Shortly thereafter, Martin and Reece, who had been employing whole-eye radiation for the treatment of retinoblastomas, also recorded retinopathy in a significant proportion of their cases, which generally developed 6-18 months after therapy. Pillat similarly noted radiationinduced retinopathy in patients receiving teletherapy for paranasal sinus malignancies and eyelid disease. ${ }^{8}$

Correspondence to: Professor D. B. Archer, FRCS, FCOphth, Department of Ophthalmology, The Queen's University of Belfast, Eye and Ear Clinic, Royal Victoria Hospital, Belfast BT12 6BA, N. Ireland.
As brachytherapy and teletherapy for selected retinoblastomas became routine practice and were also extended to certain melanomas of the choroid with high dose schedules, reports of associated retinal vasculopathy became commonplace. ${ }^{9-27}$ The regularly cited retinal microvascular changes were microaneurysms, dilated and telangiectatic vessels, and all grades of vascular sheathing, obstruction and occlusion. Retinal haemorrhage, exudation and infarction were common findings, whereas retinal neovascularisation, detachment and optic neuropathy were encountered less frequently.

The introduction of fluorescein angiography allowed a more detailed assessment of microvascular changes, and numerous studies confirmed that all components of the retinal and choroidal vasculature could be affected by radiation doses in the therapeutic range. ${ }^{27-32}$ The key changes were distortion and disruption of the architecture of the retinal microvasculature associated with capillary incompetence and occlusion. Intraretinal, preretinal and papillary neovascularisation complicated widespread retinal ischaemia. The changes, not unlike those of diabetic retinopathy or tributary vein occlusion, merely highlighted the limited number of ways that retinal vessels could respond to noxious influences or an altered environment.

The choroidal circulation was also profoundly affected by high doses of radiation delivered to the tumour base by plaque therapy, and partial or total loss of choroidal vessels occurred at and adjacent to the treated neoplasm. The retinal pigment epithelium showed a range of atrophic, proliferative and migratory alterations, and although these were most pronounced where the choroidal circulation was deficient, they also occurred independently of identifiable choroidal insufficiency.

The precise effects of both brachytherapy and teletherapy on the retinal vasculature were often difficult to decipher as some patients had supplementary photocoagulation or cryotherapy for retinal or choroidal tumours. Furthermore, substances liberated from necrotic melan- 
omas or retinoblastomas and products of radiationinduced inflammation might well have affected the nearby microvasculature, whether the influence was vasostimulatory or inhibitory. ${ }^{27}$

Retinal vascular changes following teletherapy to eyes without tumour were easier to interpret, and in the past two to three decades there has been a stream of well-documented reports of radiation retinopathy following external beam therapy for tumours of the orbit, paranasal sinuses, nasopharynx and anterior cranium where the eye was included in the treatment field. ${ }^{33-45}$ Most studies described the same spectrum of retinal vascular pathology, although choroidal vascular changes were less pronounced than those occurring with brachytherapy. Frequently, more subtle retinal microvascular alterations were appreciated when the extraocular tumours were located some distance from the eye and gratuitous ocular radiation was modest.

\section{RADIATION RETINOPATHY: NATURAL COURSE}

Despite the wealth of data outlining the protean manifestations of radiation damage to the retina and its circulation, relatively little information is available describing the earliest vascular changes and their mode of progression to established retinopathy.

Studies of the natural course of radiation retinopathy in patients receiving brachytherapy are often complicated by the use of multiple forms of treatment for intraocular melanomas or retinoblastomas, and sequential angiographic records of sufficient quality are often difficult to achieve in young children. Patients receiving teletherapy for orbital and paraorbital tumours offer the best opportunities for following the evolution of radiation retinopathy; however,

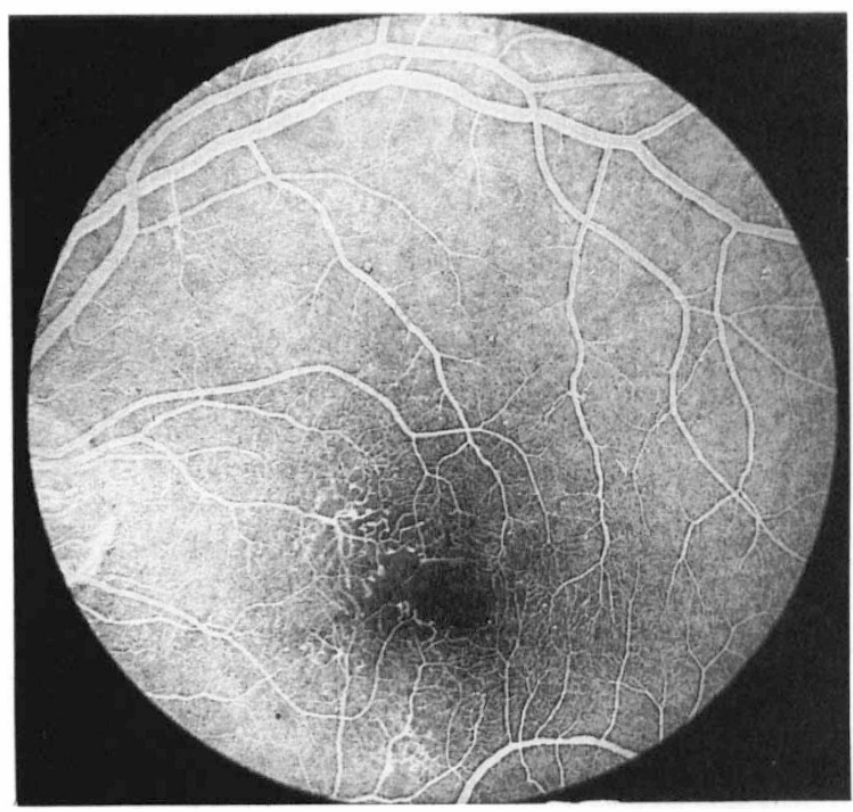

Fig. 1. Venous-phase angiogram of the left macula of a patient who received 8000 cGy for an anaplastic nasopharyngeal carcinoma. There is significant retinal capillary collapse at the macula with formation of dilated channels (capillary collaterals) and microaneurysms nasal and inferior to the foveola. Visual acuity was $6 / 6$. even in such patients longitudinal studies are often limited by poor health, diminished life expectancy and the long latency and slow progression characteristic of the disease process. Even patients suitable for follow-up may have corneal and lens opacities which militate against good angiographic data.

In our investigation the earliest retinopathic changes were identified by screening a large cohort of patients receiving cephalic radiation for orbital, paranasal and nasopharyngeal tumours. ${ }^{44,45}$ The study showed that even with modern radiotherapeutic screening techniques, some $55 \%$ of patients receiving therapy for orbital and periorbital tumours developed radiation retinopathy, and of these patients almost $50 \%$ progressed to sight-threatening vascular complications. About one-third of patients receiving radiotherapy for mid-line tumours developed bilateral retinopathy.

The earliest identifiable changes in the retinal microvasculature were focal capillary closure and irregular dilatation of the neighbouring microvasculature. The affected vessels typically remained competent in early disease, although their walls routinely stained with fluorescein during angiography. These foci were characteristically distributed about the macula, but had little effect on central vision and occurred in eyes receiving modest doses of radiation. With time, localised and insidious collapse of the capillary bed occurred and additional dilated irregular capillaries and microaneurysms formed (Fig. 1). These dilated and sometimes telangiectatic-like vessels probably represented capillary collaterals which diverted blood from occluded and defunct microvascular units. Occasionally, foci of retinopathy remained unchanged for years and became barely recognisable as affected capillaries either collapsed or regained a measure of competence.

A more exaggerated and diffuse pattern of capillary closure and dilatation became evident in patients receiving high doses of retinal radiation, with the principal pathological changes having an unerring predilection for the macular region. Dilated, tortuous and fusiform capillaries, often studded with microaneurysms, straddled areas of
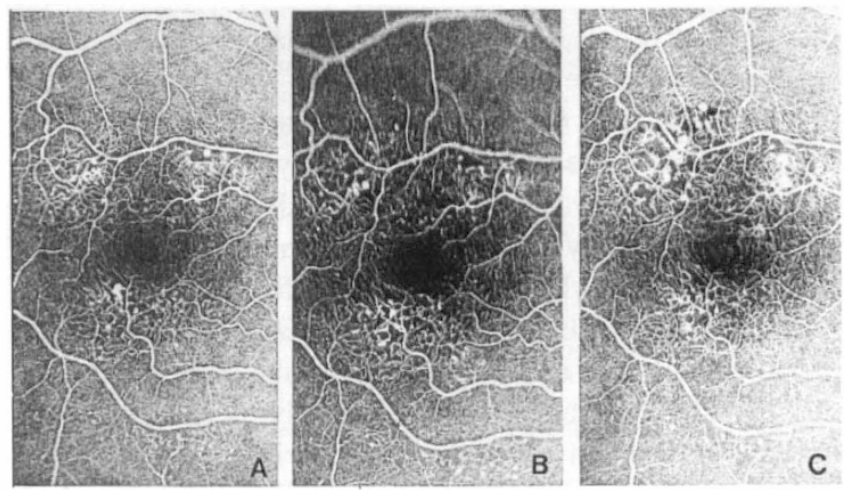

Fig. 2. Angiograms of the right macula of a patient who received 5000 cGy for a nasopharyngeal tumour. The progression of radiation retinopathy is characterised by capillary dilatation and closure and the formation and thrombosis of microaneurysms. (A) 1987; (B) 1988; (C) 1989. 
non-perfused retina. These dilated, telangiectatic-like channels were a distinctive feature of radiation retinopathy and were probably a product of altered local haemodynamics and radiation-induced changes in the capillary wall (Fig. 2). These abnormal vessels, which had a patchy distribution, usually appeared incompetent on fluorescein angiography; however, intraretinal accumulation of fluid was often not pronounced and good vision persisted for years, despite involvement of the macular and perifoveolar circulations.

Further progression of retinopathy occurred in patients receiving substantial retinal irradiation and evolved over a period of many months or years. Additional capillary beds failed to perfuse and fresh clusters of microaneurysms formed. Small numbers of intraretinal microvascular abnormalities signalled recanalisation of some occluded vessels and possibly limited formation of intraretinal new vessels. As affected vessels became increasingly incompetent, macular oedema and exudation intensified and central visual functions slowly declined.

A more acute form of ischaemic retinopathy occurred in patients subjected to intense radiation, as in the eradication of a large ocular melanoma or a mid-line nasopharyngeal tumour where only limited protection could be afforded to the posterior segment of the eye. The clinical picture, after a variable latent period, was one of ischaemic necrosis, characterised by arteriolar occlusion, extensive inner retinal ischaemia, retinal haemorrhage and cystoid macular oedema. In such instances limited retinal repair did occur and, provided the radiational damage was not extreme, some ischaemic areas of the retina became revascularised and reperfused to some degree (Fig. 3). ${ }^{46}$ In a significant proportion of patients macular oedema, exudates and axoplasmic debris resolved with corresponding improvement in visual acuity, visual fields and retinal electrophysiology.

Where retinal ischaemia was widespread, retinal or papillary neovascular membranes occasionally formed and in some instances severe vitreous haemorrhage and retinal detachment occurred. End-stage ischaemic retinopathy was occasionally associated with rubeosis iridis, secondary glaucoma and phthisis bulbi. ${ }^{44,47}$

The retinal pigment epithelium and choroidal circulation are also susceptible to ionising radiation; however, in patients receiving external beam irradiation for extraocular tumours, the gratuitous radiation rarely produced clinically observable signs beyond a fine pigmentary disturbance or isolated areas of choroidal vascular stasis. Radioactive plaque therapy for intraocular tumours, on the other hand, produced the entire range of atrophic changes of the choroid ranging from mild depigmentation to total atrophy of all choroidal vascular radicals. No clinically significant repair occurred, although we have observed two patients with atrophic scars following brachytherapy for retinoblastoma who developed choroido-retino-vitreal neovascular membranes. These membranes remained quiescent for years or decades, but following cataract extraction they leaked plasma, mimicking a recurrent tumour, or bled profusely into the vitreous, affecting vision and causing concern about the presence of a retinal tear or detachment. Choroido-vitreal membranes generally atrophied without event or responded to direct laser photocoagulation. ${ }^{48}$

Subretinal choroidal neovascularisation has been described in association with radiation retinopathy, but there is no evidence to date that radiotherapy itself contributes to the formation of subretinal neovascular membranes. New vessels arising from telangiectatic retinal vessels have been traced to the subretinal space, but were independent of the choroidal circulation. ${ }^{49}$

\section{RADIATION RETINOPATHY: THERAPEUTIC OPTIONS}

Established radiation retinopathy is, in many ways, similar to diabetic retinopathy, and it is not surprising that photocoagulation has been used to treat maculopathy and neovascularisation that pose a threat to vision. ${ }^{50}$

The number of patients developing advanced radiation retinopathy is very small and to date no randomised controlled study has properly assessed the value of photocoagulation in either limiting macular oedema or containing the vasoproliferative response. Many anecdotal reports and a few studies on small groups suggest that focal or grid laser photocoagulation has a beneficial effect on radiation-induced maculopathy, particularly in patients with early to moderate macular oedema, without cystoid degenerative changes or severe ischaemia, and who maintain moderate visual functions, i.e. 6/24 or better. ${ }^{34,35,44,50,51}$

The main effect of photocoagulation is to reduce the calibre of the dilated and deformed capillaries, improve their competence and reduce the number of microaneurysms. This is probably accomplished by diminishing cell density in the outer retina and producing an attenuated retina with lower metabolic requirements. Focal photocoagulation has proved useful for retinal and choroidal neovascularisation which occurs at or adjacent to tumour sites, following either plaque or external beam therapy. ${ }^{22,48}$

Panretinal photocoagulation has been used successfully in radiation retinopathy to eliminate or contain preretinal and papillary neovascularisation, thereby reducing the incidence of vitreous haemorrhage and retinal detachment. ${ }^{42,50,52,53}$

Persistent vitreous haemorrhage and retinal traction respond to pars plana vitrectomy ${ }^{50,54}$ and retinal detachments to conventional surgery. ${ }^{55}$

\section{RADIATION RETINOPATHY: RISK FACTORS AND LATENCY}

\section{Radiation Dose}

The total dose of radiation administered to the retina and the fraction size in the case of teletherapy are the key determinants in the development of retinopathy. In brachytherapy for retinoblastoma and choroidal melanoma, choroido-retinal vascular changes are universal, and 

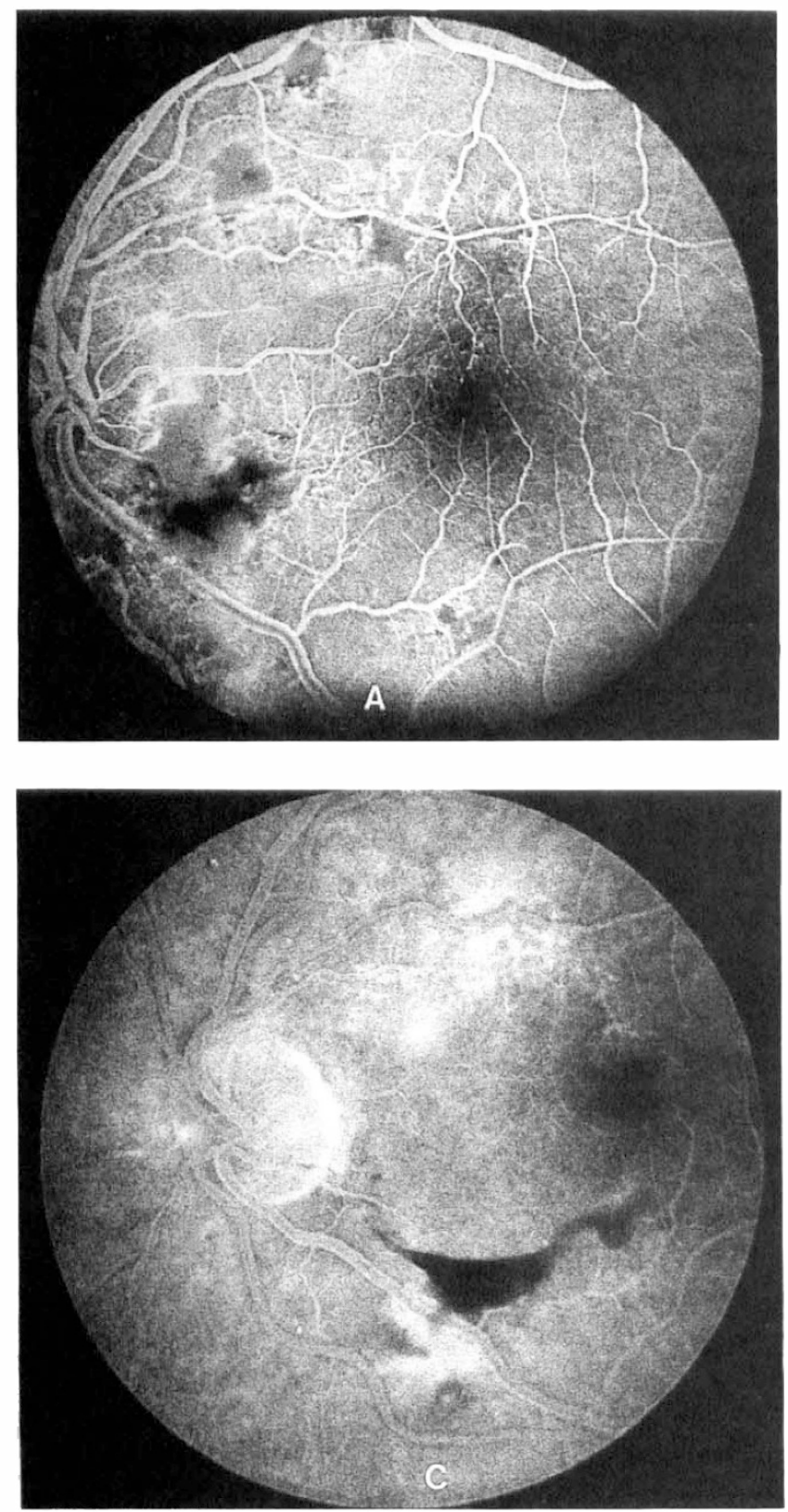

the distance to which they extend from the treatment site correlates closely with the dose of radiation employed. ${ }^{17,19,27,56-59}$ The clinical impact of such focal radiation depends on the proximity of the tumour and plaque to the macula and optic nerve head. Where large doses of radiation are used to treat choroidal melanomas (of the order of $10000 \mathrm{cGy}$ to apex and 20000-60000 cGy to base) clinically significant and visually disabling vasculopathy may extend centrifugally for some distance from the plaque site. ${ }^{30}$ Brachytherapy for melanomas posterior to the equator, and certainly within $5 \mathrm{~mm}$ of the macula, carries a significant risk of maculopathy and visual loss, although this may vary with the type of radiation administered. . $^{2460,61}$

The minimum dose of radiation required to induce maculopathy is unknown; however, one study of brachytherapy for posteriorly located retinoblastomas documented maculopathy in 7 of 18 eyes with a macular

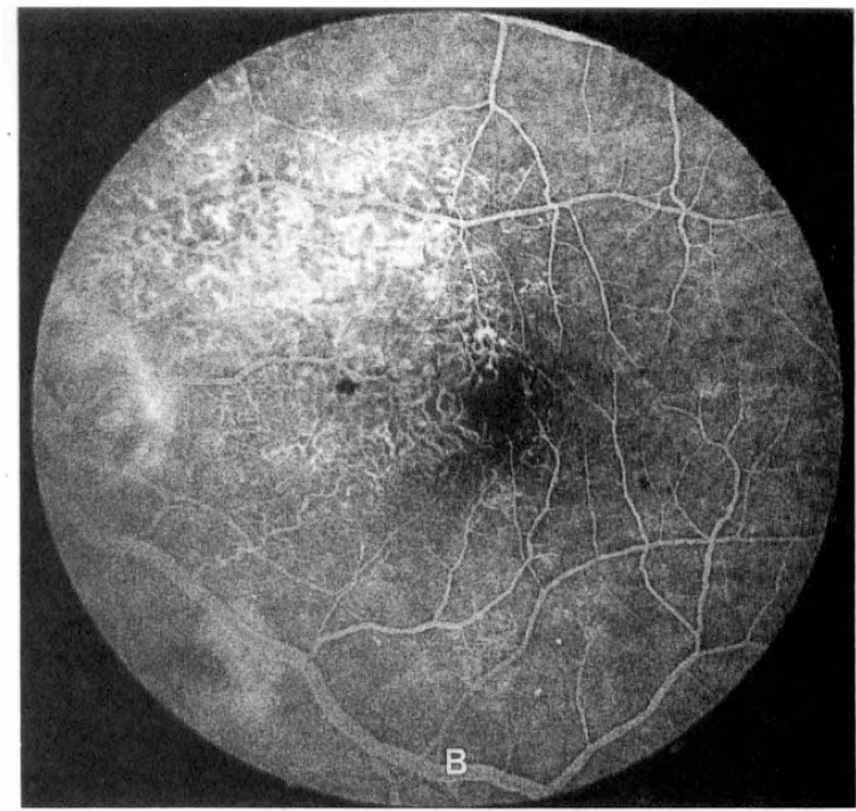

Fig. 3. Angiograms of the left macula of a patient who received 5000 cGy for an ethmoidal adenocarcinoma. There has been limited reperfusion of ischaemic retina and development of telangiectatic-like channels. The dilated vessels attenuate and achieve some competence with time. (A) 1985; (B) 1986; (C) 1992.

dose of 60 Gy or less, and in 9 of 10 eyes receiving a macular dose of $75 \mathrm{~Gy}$ or more. ${ }^{32}$ A similar study employing brachytherapy for choroidal melanomas estimated the lowest dose to induce foveal damage in non-diabetics to be in the region of $100 \mathrm{~Gy} .{ }^{27}$ The experience of some therapists is that higher doses of local radiation must be delivered to an area to inflict damage similar to that produced with external beam irradiation. ${ }^{27,56}$

The minimum amount of radiation administered by teletherapy which will give rise to retinal vasculopathy is also unknown, and estimates range from $1500 \mathrm{cGy}$ to $6000 \mathrm{cGy} .{ }^{27,33,44,62-64}$ The matter is further complicated as dose fractions and the type and rate of administration of radiation are also important parameters in the development of retinopathy. ${ }^{37,63,65-72}$

As the number of reports of early radiation retinopathy has increased and more accurate retinal dosimetry schedules have become available, more consistent information 
on threshold retinopathic doses of radiation is beginning to accumulate, although the figures are still approximate. ${ }^{27,36,73} \mathrm{~A}$ current rule of thumb is that patients receiving radiation doses of less than $2500 \mathrm{cGy}$ in fractions of 200 cGy or less, are unlikely to develop significant retinopathy. ${ }^{44}$

\section{Concomitant Chemotherapy}

Certain chemical and pharmacological agents appear to potentiate the clinical effects of ionising radiation on the retinal vasculature when administered concurrently or sequentially..$^{27,44,74,75}$ Some chemotherapeutic agents (alkylating, anti-metabolites, antibiotics) are highly reactive and form covalent bonds with DNA, thereby inhibiting DNA, RNA and protein synthesis. The antibiotics may also cause breaks within the DNA molecule, similar to those produced by ionising radiation. The inhibition of RNA or protein synthesis in non-cycling $\left(\mathrm{G}_{0}\right)$ cells will also have an important effect on DNA repair mechanisms.

The vinca alkaloids inhibit the polymerisation of microtubules and have a specific action during the mitotic phase of cell division. Certain species of the alkylating agents, e.g. nitrosoureas, are effective whether the cell is dividing or not. Thus chemotherapeutic agents can have effects which are either synergistic or additive to radiation, and in many instances both type of effects are expressed concurrently. ${ }^{76,77}$

Most reports describing the effects of combined radiation and chemotherapy on the eye show that retinal damage is particularly severe and vasculopathy remarkably extensive. ${ }^{27,44,78}$

\section{Diabetes Mellitus and Systemic Vasculopathies}

Diabetes mellitus has long been suspected as a risk factor for the development of radiation retinopathy. ${ }^{27,44,79-81}$ Theoretically, one would expect the adverse effects of both diabetes and radiation on retinal vessels to be additive or supplementary, although one recent study questions such a putative association. ${ }^{82}$ In general most clinical reports suggest that radiational vasculopathy tends to be more severe in diabetes and that inner retinal ischaemia is more extensive. Furthermore, vasoproliferation is more commonly encountered in diabetics receiving radiation to the eye than in non-diabetics.

Support for a synergistic association between the diabetic state and ionising radiation is also forthcoming from experimental work, where it has been shown that the retinal vasculature of the diabetic rat is highly susceptible to radiation in terms of capillary closure. ${ }^{83}$ Furthermore, bovine retinal vascular endothelial cells cultured under conditions of simulated hyperglycaemia are more susceptible to ionising radiation than those grown in normoglycaemic media. ${ }^{84}$

Although other studies suggest that patients with hypertension or collagen vascular diseases are more likely to develop retinopathy following radiation to the retina, these reports are mostly case studies and the association is still unproven. ${ }^{75,85}$ A particularly florid retinopathy has been recorded in a patient receiving radiation under conditions of hyperbaric oxygen.$^{86}$ This is not surprising as most damage inflicted by $\mathrm{X}$ or gamma radiation is mediated by oxygen-derived free radicals.

\section{Latency}

There is a variable delay between the time of radiation and the development of structural and clinically observable changes in the retina. Pathological alterations may become evident as early as 1 month $^{19,27,32}$ or as late as 15 years after plaque therapy, ${ }^{12}$ whilst with external beam therapy changes have been reported as early as 3 weeks and as late as 7 years after treatment. ${ }^{27,38}$ In general, the latency noted for retinopathy (mean 15 months) following brachytherapy is less than that recorded for teletherapy (mean 19 months). ${ }^{27}$ Radiation retinopathy typically develops within 6 months to 3 years after therapy; however, the difficulties experienced in mounting prospective studies and achieving regular detailed examinations in young or ill patients militate against the collection of accurate data. While there is a relationship between radiation dose and latency, the unpredictable appearance of retinal vasculopathy years after therapy still requires explanation.

\section{HISTOPATHOLOGICAL AND ULTRASTRUCTURAL INVESTIGATIONS}

Histopathological and ultrastructural studies of human retina following radiation are exceptionally sparse and for the most part record changes in the larger retinal and choroidal vessels, together with varying degrees of retinal ischaemia and atrophy. ${ }^{13,27,33,87-90}$ Few details are available concerning the early post-irradiation changes in the retinal microvasculature. Ehlers and $\mathrm{Kaae}^{32}$ in a recent and detailed review have concluded that although vaso-occlusion was a key component of radiation retinopathy, it has not been proven to be the primary event. Furthermore, the cellular changes precipitating vascular occlusion have not been identified.

Recent histological studies in our laboratory, from eyes enucleated 6-18 months following therapeutic ocular irradiation, have gone some way to clarifying these issues. ${ }^{83,91}$ Trypsin digest specimens from irradiated eyes with vasculopathy showed an early and unequivocal loss of vascular endothelial cells with relative sparing of the pericyte population, i.e. the opposite to that pertaining in diabetes mellitus. Associated changes in the capillary architecture were also common, particularly outpouchings, fusiform dilatations and microaneurysms, which predominated on the arterial side of the circulation. In more advanced disease non-perfused capillaries presented as acellular basement membrane tubes, which were often fused and collapsed.

Ultrastructural studies have also confirmed the early and preferential loss of vascular endothelial cells from occluded capillaries in which pericytes still survived. Eventually vascular occlusion occurred with loss of all vascular cells (Fig. 4). Some defunct basement membrane tubes became recanalised by fresh populations of endo- 


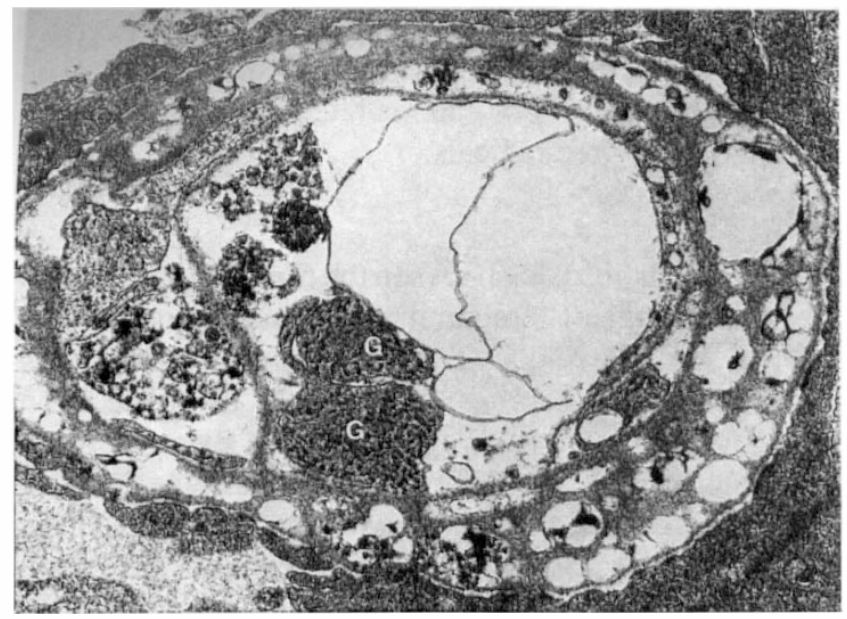

Fig. 4. Acellular capillary from a patient with radiation retinopathy, which displays degenerate remnants of vascular endothelial and pericyte cells. The lumen is invaded by two processes of glial cells $(G) .(\times 8900)$

thelial and pericyte cells which elaborated their own basal lamina within the atrophic vessels (Fig. 5). Some of these newly formed capillaries were unusual in that their endothelial cells displayed fenestrations, a feature of less specialised extraretinal (non central nervous system) capillaries.

Large, thin-walled channels, encapsulated by a dense adventitia of collagen fibrils, were often found in eyes with more advanced retinopathy and probably corresponded to the dilated telangiectatic vessels found in patients with established vasculopathy. These abnormal channels were mostly found in degenerative retina, and although located intraretinally, often had a fenestrated endothelium (Fig. 6). It is tempting to speculate that the separation of the endothelial cells from the retinal glia by the collagenous capsule in such vessels allowed the endothelium to revert to a less specialised, fenestrated form.

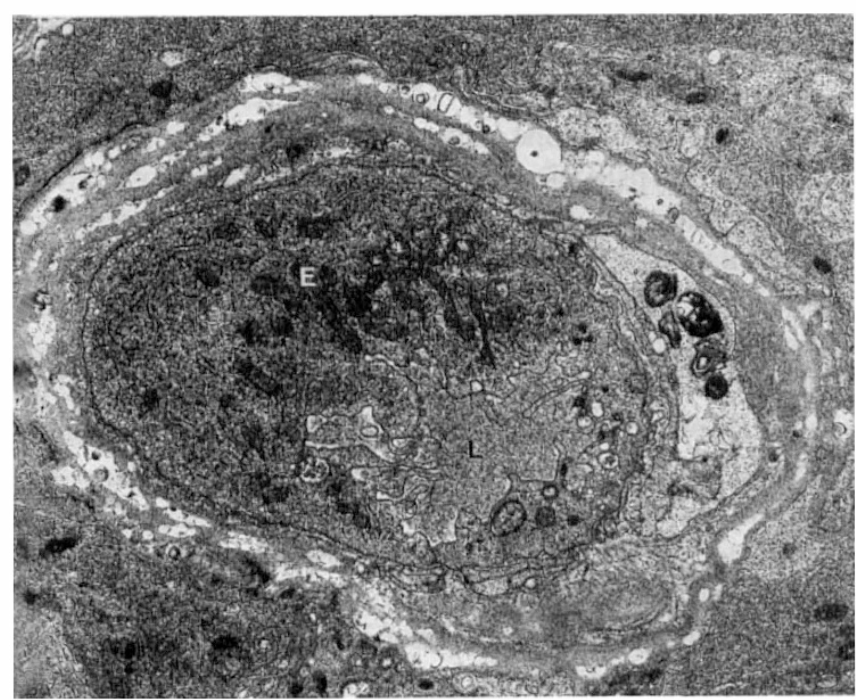

Fig. 5. A new intraretinal vessel invades redundant acellular basement membranes of a defunct capillary (same patient as in Fig. 4). The plump vascular endothelial cells $(E)$ have a rich complement of intracytoplasmic organelles. L, lumen. $(\times 6610)$

\section{RADIATION RETINOPATHY: SOME EXPERIMENTAL OBSERVATIONS}

A host of experimental studies have detailed the effects of ionising radiation on the retina, some dating back to the time of the discovery of X-rays. The vast majority of investigations, however, were primarily concerned with determining threshold levels at which varying doses of radiation induced biochemical, electrophysiological and histological alterations to the retinal neuropile and its component cells. Some studies also documented changes occurring in the retinal vasculature, but these alterations were usually of subsidiary interest and generally followed exposure of the eye to large single doses of radiation, giving few clues to the early development of the radiationinduced vasculopathy. ${ }^{92-103}$

More recently Irvine and associates studied the response of the primate retinal vasculature to single doses of radiation between 2500 and 4000 cGy. ${ }^{104,105} \mathrm{An}$ ischaemic vasculopathy developed with early loss of capillary pericytes and endothelial cells, and although some limited proliferation of intraretinal new vessels occurred, the predominant picture was one of haemorrhagic necrosis and atrophy of the retinal neuropile. The large single doses of radiation employed in this study may have obscured to some extent the differential response of the retinal pericytes and endothelial cells to radiation-induced damage.

In an attempt to define the earliest microvascular changes, we exposed the retinae of the Lister rat, which has a vasculature very comparable to the human, to a wide range of single doses of radiation (200-2000 cGy) and produced capillary changes that closely mimicked those occurring in clinical radiation retinopathy. ${ }^{83,106}$ The changes were most evident between 6 months and 1 year after exposure to 1500-2000 cGy, and the earliest observable pathology was elongation of the capillary endothelial cell nuclei and narrowing of the capillary lumen. More affected vessels showed endothelial cell loss and capillary closure, although pericytes typically survived within the wall of the collapsed basement membrane tube for some

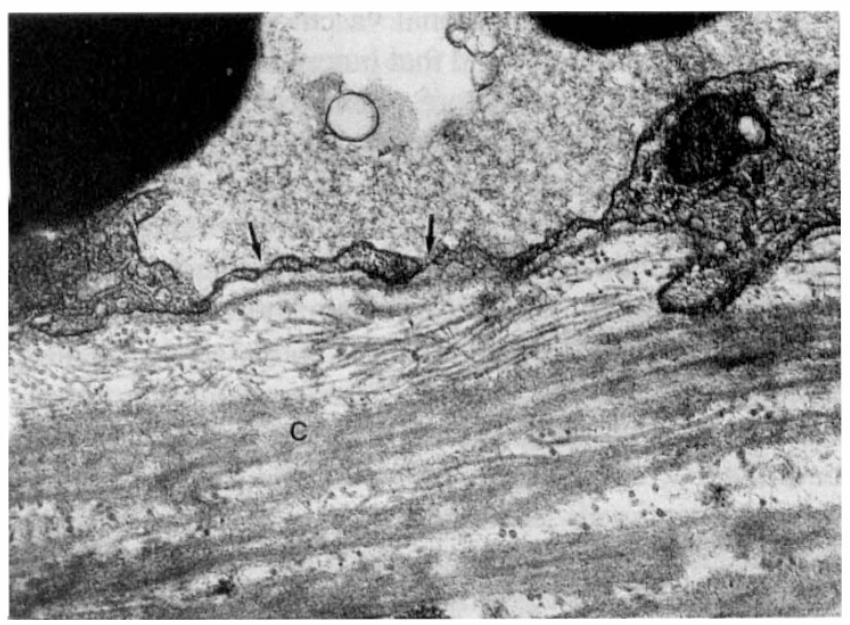

Fig. 6. Electron micrograph of telangiectatic-like vessel from the same patient shown in Fig. 4. The attenuated vascular endothelium displays fenestrations (arrows) and is enveloped by a dense collagenous adventitia $(C) .(\times 21000)$ 


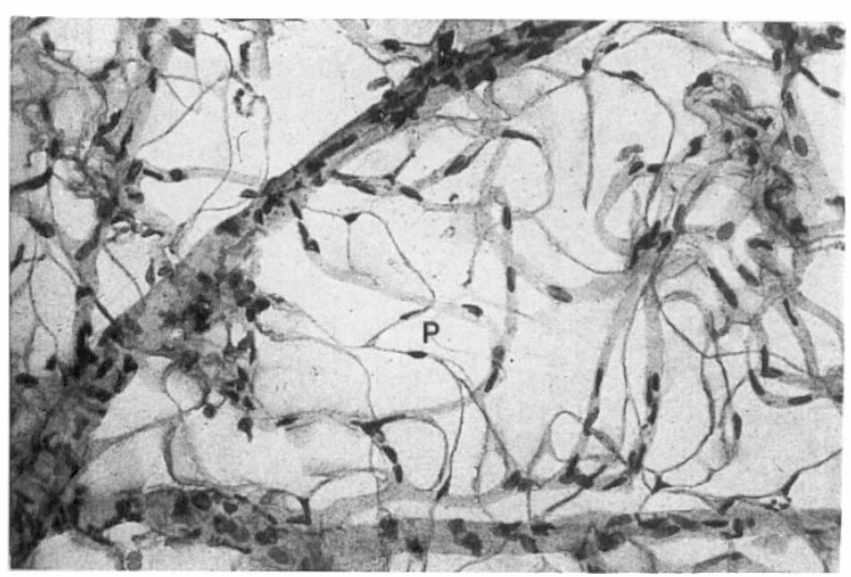

Fig. 7. Trypsin digest specimen of Lister rat retina aged 6 months, following exposure to 1.50$)($ ) $G y$ of $X$-ravs. Acellular capillaries are evident as collapsed and fiused basement membranes. In some collapsed capillaries pericite's $(P)$ remain despite the absence of endothelial (ells. $(\times 25())$

time after the loss of the endothelium (Fig. 7). Severely damaged capillaries were acellular and reduced to fine strand-like structures, consisting of residual basement membrane. Rarely, some of these defunct channels showed evidence of recanalisation with new endothelial tubes. Although microaneurysms were not evident some retinal veins revealed telangiectatic-like changes in the form of a highly irregular attenuated endothelium and a thick fibrous adventitia. There was no suggestion of vasoproliferation in this model.

The retinal neuropile itself was remarkably radioresistant with the exception of the photoreceptor cells, which showed characteristic early membrane changes in the rod outer segments with low-dose irradiation and atrophy and cell death with larger doses.

In view of the reported sensitivity of the diabetic retinal vasculature to radiation, we exposed the eyes of 5-8.5 months streptozotocin-diabetic Wistar rats to 1000-1500 cGy of $90 \mathrm{kVp} \mathrm{X}$-rays in an attempt to extend and intensify the vasculopathy and perhaps induce vasoproliferation. Such radiation produced striking retinal vascular occlusion with areas of profound inner retinal ischaemia as evidenced by the presence of cytoid bodies in the nerve fibre layer. The principal vascular findings were endothelial cell loss and collapse of the grossly thickened basement membrane tubes. Some capillaries and arterioles also showed pericyte and smooth muscle cell depletion. In some eyes intraretinal and preretinal new vessels were observed, clearly indicating the synergistic effect of diabetes and radiation on the retinal microvasculature, as neither prolonged diabetes nor radiation injury by themselves have been shown to promote neovascularisation in the rat.

The twin insults of diabetes and radiation on the retina and its vasculature faithfully reproduced the vasoproliferative response that is noted in diabetes, retinal vein obstruction, sickle cell disease and other clinical occlusive vasculopathies. The new vessels formed in areas characterised by inner retinal ischaemia, breached the internal limiting membrane, and proliferated in the vitreous cavity (Fig. 8). Retinal neovascularisation has been described in a variety of experimental models; however, in most of these, inner retinal ischaemia was not the predominant feature. ${ }^{107-1109}$ As in the clinical situation, the preretinal new vessels in irradiated diabetic rats had fenestrated endothelia. Thus, most of the clinical features of radiation retinopathy can be reproduced in the experimental animal with the exception of microaneurysms, which do not appear to be a feature of either diabetic or radiation retinopathy in the rat. ${ }^{106}$

The retinal pigment epithelium and choroidal circulation were less radiosensitive than the inner retinal vasculature; however, exposure to 1600-2000 cGy showed a patchy degeneration of retinal pigment epithelial cells and some evidence of thrombosis in the choriocapillaris.

\section{RADIATION RETINOPATHY: CELL KINETIC AND TISSUE CULTURE STUDIES}

In the ordinary course of events capillary endothelial cell loss is made good by cell division, coupled with migration and spreading of adjoining cells. Theoretically, endothelial cell loss caused by ionising radiation should precipitate a wave of cell division in order to maintain integrity of the endothelial lining and prevent thrombosis. Cell turnover studies in the irradiated rat retina (1000-2000 cGy) administered $\left[{ }^{3} \mathrm{H}\right]$ thymidine over a 48-hour period showed little change in endothelial cell labelling in the first week. However. by 6 months post-irradiation there was a 5- to 10-fold increase in microvascular cells engaged in DNA synthesis. This pronounced increase in the labelling index of microvascular cells suggests that the pace of cell division accelerates to replace endothelial cells lost due to radiation-induced mitotic death or delayed interphase death."

Cell culture preparations offer a convenient and controlled environment in which to test the effects of radiation on pure isolates of vascular endothelial cells and pericytes. It has been shown that retinal microvascular pericytes and endothelial cells display a similar order of radiosensitivity in culture. Both cell types demonstrated significant radiation injury at doses above $300 \mathrm{cGy}$ and failed to replicate at doses in excess of $400 \mathrm{cGy} .{ }^{111}$

\section{RADIATION RETINOPATHY: MOLECULAR BIOLOGICAL VIEWPOINT}

The absorption of ionising radiation by a cell leads to a complex series of biological events determined by the nature and dose of the radiation, the type of cell, its stage in the cell cycle and its antioxidant status. The target atoms or molecules of the cell may be directly excited and ionised by the incident radiation or indirectly affected by the action of free radicals generated by the radiation."'

Ionising radiation has specific and deleterious effects on retinal cell membranes and organelles, but it is damage to the cell nucleus and genetic apparatus that principally determines the function and fate of the cell post-injury. Intense radiation (lethal doses) causes irreversible nuclear 


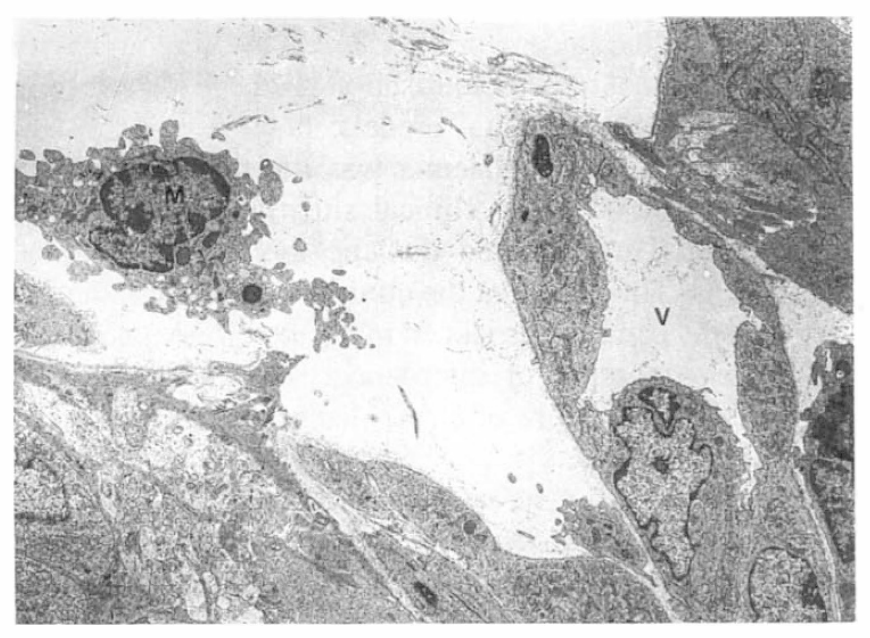

Fig. 8A.

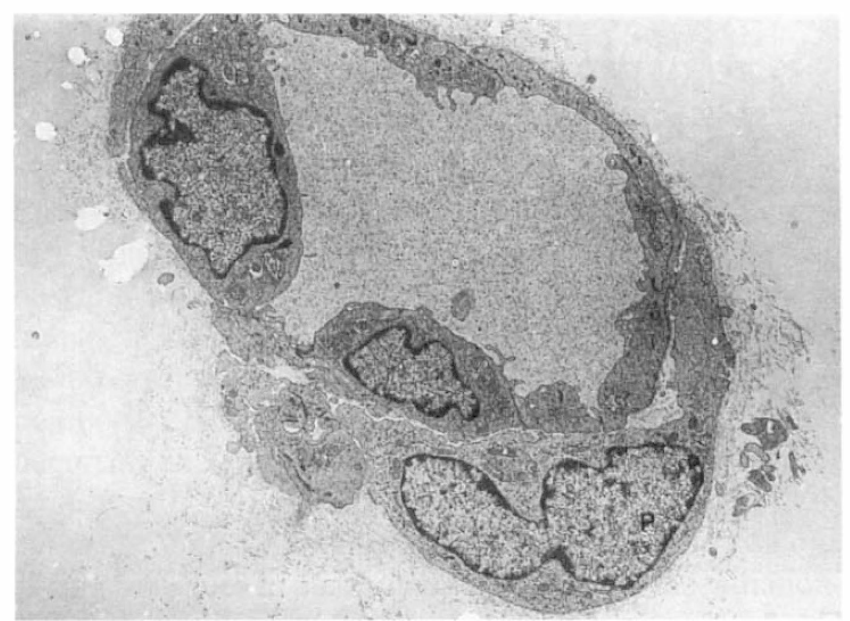

Fig. 8B.

Fig. 8. (A) Retina from 1-year-old diabetic Wistar rat exposed to 1500 cGy of X-rays after 5 months of diabetes. A new retinal vessel $(V)$ has breached the internal limiting membrane of the retina to enter the vitreous cavity. The new capillary is composed of large organelle-rich vascular endothelial cells and is accompanied by macrophages (M). ( $\times 2200)$. (B) Cross-section of an intravitreal new vessel in the rat retina shown in (A). The mature vascular endothelial cells are secured by junctional complexes and encompassed by pericyte cells $(P)$ which form junctions with the abluminal plasma membranes of the endothelial cells. A tenuous basement membrane surrounds the vascular cells. $(\times 3900)$

damage and cell death. Sublethal radiation, whilst not precipitating cell death, may have severe biological repercussions due to alterations in the reproductive capacity of the cell and changes in RNA activity with knock-on effects in the synthesis of cellular proteins.

The survival of the cell is inextricably linked to the type of radiation damage inflicted on the genomic DNA. Single strand breaks which occur through the disruption of sugar-phosphate bonds can be repaired by removal of the damaged portion of the DNA strand and subsequent repair synthesis by the appropriate DNA polymerases and ligase.

Double strand breaks in DNA endanger cell survival as they are often irreparable due to the loss of structural integrity and the lack of an undamaged DNA template on either strand at the site of the fracture. If the portion of genomic DNA damaged by radiation is not essential to the survival or proper functioning of the cell, or if the gene is reduplicated elsewhere, there may be little immediate observable change in the injured cell. Nevertheless, on attempted division, chromosomal breaks or perturbations which are incompatible with cell survival and normal function may occur.

The relative radioresistance of the retina to ionising radiation has traditionally been attributed to its stable population of nerve cells, as it is well known that cells undergoing mitosis are particularly susceptible to the lethal effects of radiation. ${ }^{112}$ However, there may be other cellular attributes that determine how retinal cells respond to radiation, and recent studies suggest that the conformation of nuclear chromatin may be important in this respect. ${ }^{113}$ It has been shown that the photoreceptors of the rat retina are highly radiosensitive even though they are noncycling central nervous system neurones. ${ }^{114}$ By comparison, human rod photoreceptors are relatively radioresis- tant, although less so than cones. The most obvious morphological difference between the human and rat rod photoreceptor cells is the nature of their nuclear chromatin (DNA and nuclear proteins). In rat rods the chromatin is highly clumped (heterochromatic) while in human rods it is relatively finely dispersed (euchromatic) throughout the nucleoplasm (Fig. 9). It would seem, therefore, that chromatin is more vulnerable to irreparable radiation damage when tightly packed as heterochromatin than when finely dispersed as euchromatin.

This conclusion is consistent with the observation that cells are most radiosensitive during mitosis ${ }^{115}$ when their chromatin is maximally condensed; and compatible with several studies which demonstrate that although more DNA damage occurs in active chromatin during DNA ${ }^{116}$ or RNA ${ }^{117,118}$ synthesis, such damage is easily repaired in comparison with that within the relatively inactive mitotic chromosomes ${ }^{119,120}$ or heterochromatin of the nuclear periphery. ${ }^{121,122}$

Several studies have suggested that radiation damage to the least active regions of the genome, such as those which reside within heterochromatin, may be the most critical for cell survival. ${ }^{113,120,122}$ The evidence that DNA damage within active chromatin appears to be more efficiently repaired may be explained by the 'differential accessibility' hypothesis of Wheeler et al. ${ }^{113}$ This concept suggests that DNA involved in synthesis is more accessible to repair enzymes than inactive regions located within tightly bound heterochromatin or mitotic chromosomes.

The retinal vascular endothelial cells are distinctively heterochromatic, with the bulk of the chromatin concentrated in dense aggregates around the nuclear envelope. Accordingly, it is not surprising that they are much more radiosensitive than the inner retinal neurones whose nuclei 


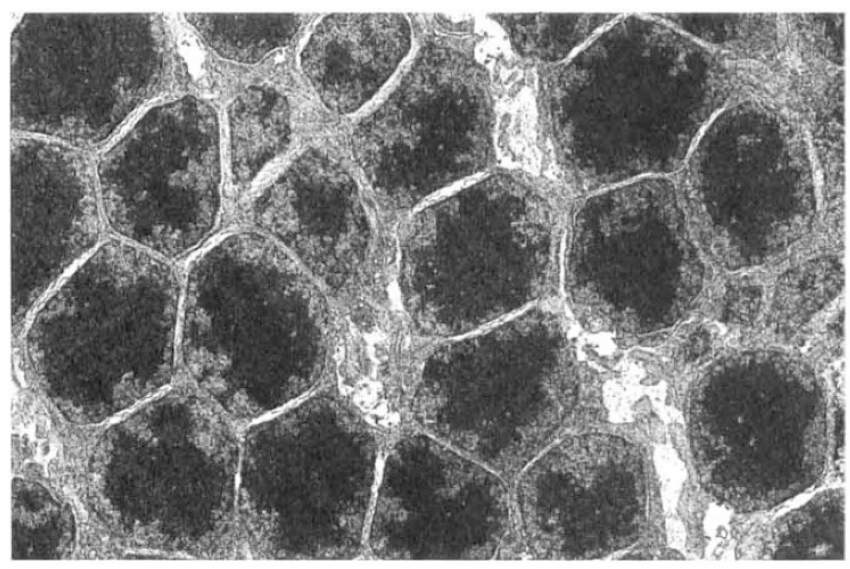

Fig. 9A.

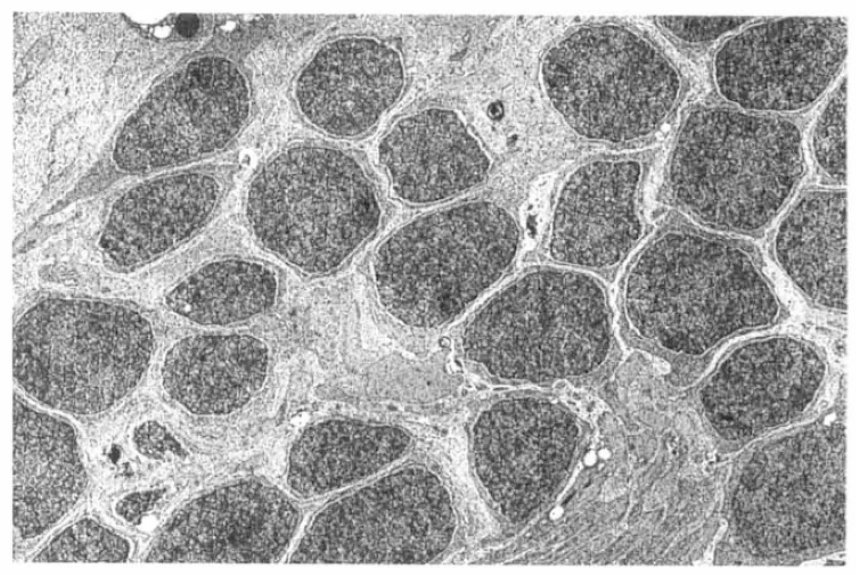

Fig. 9B.

Fig. 9. (A) Electron micrograph of nuclei of rat rod photoreceptors showing the highly condensed conformation of nuclear chromatin. $(\times 2000)$. (B) The nuclei of human rod photoreceptors show relatively euchromatic nuclear chromatin. $(\times 2015)$

are highly euchromatic (Fig. 10). Retinal vascular cells undergoing mitosis would be expected to be particularly vulnerable in comparison with retinal neurones.

\section{RADIATION RETINOPATHY: A SYNTHESIS OF PERSPECTIVES AND HYPOTHESIS}

Although the clinical features of radiation retinopathy have been recognised for some time and are remarkably similar for different types of ionising radiation of equivalent dose, the pathogenesis of the microangiographic changes and the variable natural course have been poorly understood. The peculiar and inconsistent latency of the retinopathy has been an enigma since its recognition more than half a century ago.

The convergence of clinical, histopathological and experimental investigations has provided new insights
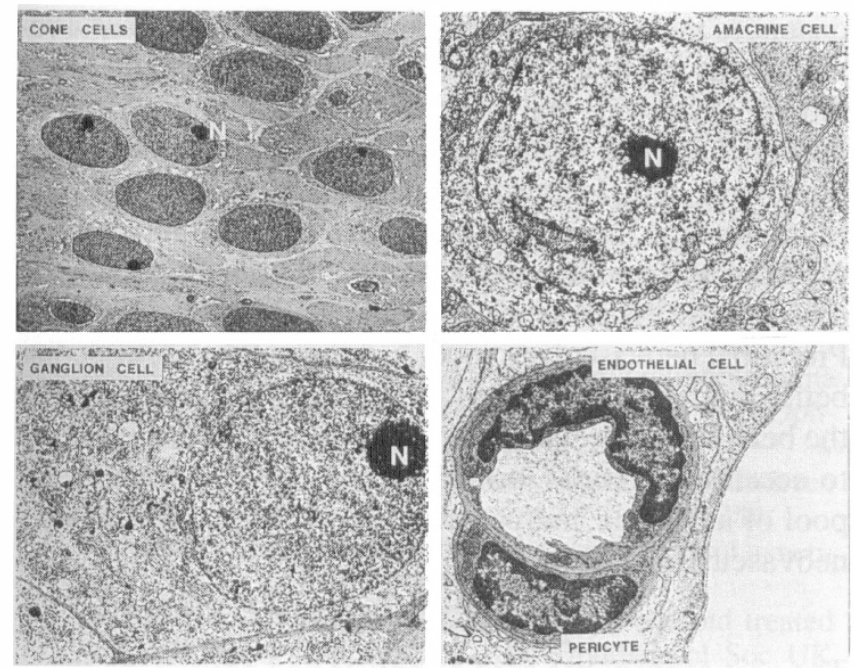

Fig. 10. Electron micrographs of nuclei of human, cone, amacrine, ganglion and vascular cells to show the conformation of nuclear chromatin. The nuclear chromatin of the cone, amacrine and ganglion cells is finely dispersed throughout the nucleoplasm, i.e. is euchromatic. The chromatin of the vascular endothelial cell and pericyte is typically heterochromatic and condensed about the perinuclear membrane. $N$, nucleoli. into the behaviour of retinal vascular cells following radiation injury and revealed much fresh information concerning the reorganisation of the retinal capillary bed. Recent radiobiological data also go some way to explaining the relative radiosensitivity of the retinal vascular cells and have helped to develop a working hypothesis to explain the variable time of onset of retinopathy following radiation damage.

We propose that exposure of the retinal vascular bed to ionising radiation sufficient to precipitate retinopathy causes immediate changes at the molecular level as the result of direct or indirect damage to cell membranes and proteins but most of all to nuclear DNA. A small, scattered population of vascular endothelial cells, approaching or involved in mitosis at the time of irradiation, undergoes immediate mitotic death due to irreparable damage to genomic DNA. Some cells will also suffer interphase death due to overwhelming free radical or ionising damage to the nucleus and other key cellular components. The higher the dose of radiation the greater the number of cells which suffer such damage.

Cell damage predominates on the arterial side of the circulation where free radical generation is exaggerated by the high oxygen tension. Endothelial cell damage may also be accentuated by the presence of transition metals such as iron and copper in the plasma, which catalyse the production of free radicals.

The first wave of vascular cell death initiates migration and expansion of endothelial cells whilst causing others to divide in order to repair the primary endothelial cell defect and maintain rheological integrity of the vascular lumen. However, some of these surviving cells will have sustained radiation damage, and the forced division may precipitate further mitotic death due to major defects in their nuclear DNA. This sequence of events may be repeated several times until the surviving healthy endothelial cells are unable to maintain a continuous endothelium and the clotting cascade is activated with subsequent capillary occlusion (Fig. 11). 


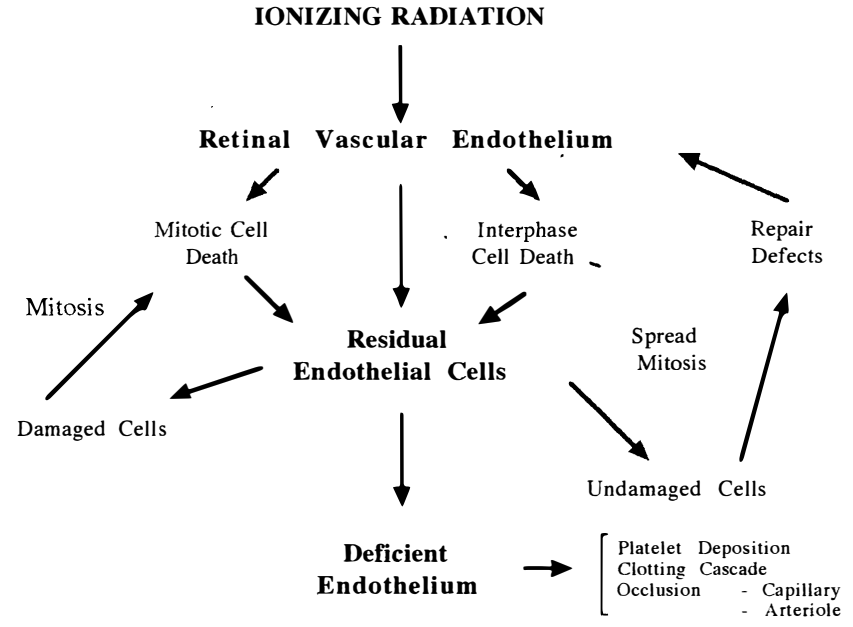

Fig. 11. Pathogenesis of radiation retinopathy: a proposed scheme of cellular events.

The result of this progression is occlusion of discrete regions of the capillary bed with increased haemodynamic stress imposed on neighbouring capillaries, some of which may also have been compromised by endothelial cell loss. With time, fresh waves of vascular endothelial cell loss can be anticipated, as genomically damaged cells undergo mitotic death while attempting to divide in the normal course of endothelial cell renewal, thereby initiating a further round of local cell death and capillary occlusion. The vascular endothelium may also be depleted by delayed interphase death of cells that have exhausted vital cytoplasmic components which cannot be replenished because of strategic damage to their nuclear DNA.

The long latency of radiation retinopathy after the initial radio-insult is probably related to the life cycle of the retinal vascular endothelial cell. The vascular endothelial cells of the retina constitute a highly stable population of cells with only a small number engaged in mitotic or cycling activity at any given time. ${ }^{123,124}$ For this reason the mitotic death of endothelial cells and resultant angiopathy may be appreciably delayed following radiation damage. It is probable that the major effects attributable to radiation-damaged cells will have become manifest within a period of 2-3 years. Nevertheless, a small number of compromised cells may survive for many years unless local or systemic pathological conditions, for example diabetes or hypertension, require them to divide, causing further endothelial cell loss. This is probably the case for most patients receiving modest doses of radiation, i.e. $2500 \mathrm{cGy}$ or less and administered in fractions of not more than $200 \mathrm{cGy}$.

Where the retina has sustained severe radiational damage (probably in excess of $4000 \mathrm{cGy}$ ) more widespread capillary closure occurs and intensifies with time. As capillaries thrombose and atrophy, blood is diverted into neighbouring channels which dilate under the undue haemodynamic load and become clinically apparent on fluorescein angiography as capillary collaterals. Some such vessels may remain stable and competent for years, while others become grossly irregular and develop saccular outpouchings and microaneurysms along their walls, gradu- ally becoming increasingly incompetent. In time the affected capillary bed undergoes a subtle remodelling, with new collaterals and microaneurysms forming as additional channels thrombose, atrophy and disappear from angiographic view. As the disease process intensifies, certain capillary collaterals and their associated venules become grossly dilated under the haemodynamic load and assume a telangiectatic-like appearance which is typical if not pathognomonic for radiation injury. These dilated channels become encapsulated within a collagen-rich adventitia which insulates them from the surrounding neuropile and may lead to the development of a fenestrated type of endothelium.

It is remarkable how consistently the macular circulation is involved in radiation retinopathy. This phenomenon may be a function of capillary density and the high tissue oxygen levels which are a feature of this region. It has also been noted that endothelial cell turnover is particularly high in small capillaries, rendering them more susceptible to radiational damage. ${ }^{125}$

When the retina is exposed to inordinately high doses of radiation (generally 6000-7000 cGy), e.g. in the course of treating large melanomas or nasopharyngeal tumours where shielding is impracticable, damage may be widespread, involve arterioles, and result in extensive closure of the retinal capillary bed. In such circumstances endothelial damage is so severe that continuity of the endothelium cannot be preserved in many of the larger vessels, particularly on the arterial side of the circulation. Widespread inner retinal ischaemia results, although revitalisation of some infarcted areas occurs slowly as some channels reopen and others become relined with fresh endothelial tubes.

The rate of change in established radiation retinopathy is slow and capillary regeneration is typically muted. New intraretinal vessels do form, but these extend only short distances and are probably functionally insignificant. Preretinal and papillary neovascularisation only occur where retinal ischaemia and atrophy is widespread. Vitreous haemorrhage and retinal detachment are uncommon complications, and isolated preretinal fronds may remain asymptomatic for years. Extraretinal vasoproliferation has not been reported in experimental radiation retinopathy to date, even in the presence of widespread retinal ischaemia. Preretinal neovascularisation, however, does occur in diabetic animals subjected to radiation, which underscores the belief that the diabetic and radiational insults conspire to accentuate retinal ischaemia and create the necessary pool of autocrine and paracrine growth factors to initiate neovascularisation.

\section{CONCLUSION}

The past century has seen scientists and physicians strive to harness and deploy various forms of ionising radiation to contain or cure a host of disease processes. Success in treating the primary pathology in most instances has had to be weighed against unwanted side effects of radiation on normal tissues, and often the equation was finely balanced. 
As the sources, forms and intensity of ionising radiation have become better controlled and quantified, and delivery to target tissue has become more precise, the therapeutic effects have begun significantly to outweigh the unwanted complications. As techniques for irradiation of ocular, orbital and cephalic tumours are becoming more discriminating, the incidence of sight-threatening radiation retinopathy should decrease. Nevertheless, the priority accorded to tumour eradication may expose the ocular fundus to retinopathic doses of radiation, and close cooperation between radiotherapists and ophthalmologists is vital in order to identify patients at risk of developing clinically significant retinopathy.

Studies of radiation retinopathy over the years have highlighted important differences in the radiosensitivity of the component cells of the retina and even different parts of the same cell. The susceptibility of the retinal vascular endothelium to substantial doses of radiation is the key radiobiological factor leading to vascular occlusion and development of retinopathy, and the physical conformation of nuclear chromatin in the endothelial cell seems an important factor in its vulnerability. The variable latency of radiation retinopathy is probably also a function of retinal vascular endothelial cell biology, reflecting the small scattered populations of cells engaged in cycling or mitotic activity at any given time.

\section{REFERENCES}

1. Chalupecky H. Über die Wirkung der Röentgenstrahlen auf das Auge und die Haut. Zentralbl Prakt Augenheilk 1897;21:234-9.

2. Birch-Hirschfeld GVA. Zur Wirkung der Röentgenstrahlen auf das menschliche Auge. Klin Monatsbl Augenheilkd 1908;46:129.

3. Rohrschneider W. Experimentelle Untersuchungen über die Veränderungen normaler Augengewebe nach Röentgenbestrahlung. III. Veränderungen der Linse der Netzhaut und des Sehnerven nach Röentgenbehstrahlung. Albrecht von Graefes Arch Klin Exp Ophthalmol 1929;122;282-90.

4. Stallard HB. Radiant energy as (a) a pathogenic (b) a therapeutic agent in ophthalmic disorders. Br J Ophthalmol Monograph Suppl 1933;6:1-126.

5. Stallard HB. Glioma retinae treated by radon seeds. BMJ 1936;2:962-4.

6. Moore FR. Reports: 1. Presidential address. The value of radium in intraocular lesions. Trans Ophthalmol Soc UK 1935;55:3-26.

7. Martin $\mathrm{H}$, Reece AB. Treatment of bilateral retinoblastoma (retinal glioma) surgically and by irradiation. Arch Ophthalmol 1945;33:429-39.

8. Pillat A. Fall seltener Röntgenschädigung am Hinderen Augenpol. Klin Monatsbl Augenheilkd 1935;94:384.

9. Stallard HB. Radiotherapy of malignant intraocular neoplasms. Br J Ophthalmol 1948;32:618-39.

10. Stallard HB. Malignant melanoma of the choroid treated with radioactive applicators. Trans Ophthalmol Soc UK 1959;79:373-92.

11. Stallard HB. The conservative treatment of retinoblastoma. Trans Ophthalmol Soc UK 1962; 82:473-534.

12. Stallard HB. Radiotherapy for malignant melanoma of the choroid. Br J Ophthalmol 1966;50:147-55.

13. Howard GM. Ocular effects of radiation and photocoagulation. Arch Ophthalmol 1966;76:7-10.

14. Bedford MA, Bedotto C, MacFaul PA. Radiation retino- pathy after the application of a cobalt plaque. $\mathrm{Br} \mathrm{J}$ Ophthalmol 1970;54:505-9.

15. Lommatzsch PK. Treatment of choroidal melanomas with ${ }^{106} \mathrm{Ru} /{ }^{106} \mathrm{Rh}$ beta-ray applicators. Surv Ophthalmol 1974; 19:85-100.

16. Lommatzsch PK. Experiences in the treatment of malignant melanoma of the choroid with ${ }^{106} \mathrm{Ru} /{ }^{106} \mathrm{Rh}$ beta-ray applicators. Trans Ophthalmol Soc UK 1973;93:119-32.

17. Lommatzsch PK. $\beta$-Irradiation of choroidal melanoma with ${ }^{106} \mathrm{Ru} /{ }^{106} \mathrm{Rh}$ applicators. Arch Ophthalmol 1983;101: 713-7.

18. Lommatzsch PK. Results after $\beta$-irradiation $\left({ }^{106} \mathrm{Ru} /{ }^{106} \mathrm{Rh}\right)$ of choroidal melanomas: 20 years' experience. $\mathrm{Br} \mathrm{J}$ Ophthalmol 1986;70:844-51.

19. Char DH, Lonn LI, Margolis LW. Complications of cobalt plaque therapy of choroidal melanomas. Am J Ophthalmol 1977;84:536-41.

20. Char DH. The management of small choroidal melanomas. Surv Ophthalmol 1978; 22:377-86.

21. Ellsworth RM. Retinoblastoma. Mod Probl Ophthalmol 1977;18:94-100.

22. Egbert PR, Donaldson SS, Moazed K, Rosenthal AR. Visual results and ocular complications following radiotherapy for retinoblastoma. Arch Ophthalmol 1978;96: 1826-30.

23. Egbert PR, Fajardo LF, Donaldson SS, Moazed K. Posterior ocular abnormalities after irradiation for retinoblastoma: a histopathological study. Br J Ophthalmol 1980;64:660-5.

24. Cruess AF, Augsburger JJ, Shields JA, Donoso LA, Amsel J. Visual results following cobalt plaque radiotherapy for posterior uveal melanomas. Ophthalmology 1984;91: $131-6$.

25. Rotman M, Long RS, Packer S, Moroson H, Galin MA Chan B. Radiation therapy of choroidal melanoma. Trans Ophthalmol Soc UK 1977;97:431-5.

26. Shields JA, Augsburger JJ, Brady LW, Day JL. Cobalt plaque therapy of posterior uveal melanomas. Ophthalmology 1982;89:1201-7.

27. Brown GC, Shields JA, Sanborn G, Augsburger JJ, Savino PJ, Schatz NJ. Radiation retinopathy. Ophthalmology 1982;89:1494-501.

28. Hayreh SS. Post-radiation retinopathy: a fluorescence fundus angiographic study. Br J Ophthalmol 1970;54:705-14.

29. Tarkkanen A, Laatikainen L. Fluorescein angiography in the long-term follow-up of choroidal melanoma after conservative treatment. Acta Ophthalmol (Copenh) 1985;63: 73-9.

30. Elmassri A. Radiation chorioretinopathy. Br J Ophthalmol 1986;70:326-9.

31. Lommatzsch PK, Ballin RE, Helm W. Fluorescein angiography in the follow-up study of choroidal melanoma after ${ }^{106} \mathrm{Ru} /{ }^{106} \mathrm{Rh}$ plaque therapy. Retina 1987;7:148-55.

32. Ehlers N, Kaae S. Effects of ionizing radiation on retinoblastoma and on the normal ocular fundus in infants: a photographic and fluorescein angiographic study. Acta Ophthalmol (Copenh) 1987;65(Suppl 181):1-84.

33. Perrers-Taylor M, Brinkley D, Reynolds T. Choroido-retinal damage as a complication of radiotherapy. Acta Radiol Ther Phys Biol 1965;3:431-40.

34. Chee PHY. Radiation retinopathy. Am J Ophthalmol 1968; 66:860-5

35. Gass JDM. A fluorescein angiographic study of macular dysfunction secondary to retinal vascular disease. VI. $\mathrm{X}$-ray irradiation, carotid artery occlusion, collagen vascular disease and vitritis. Arch Ophthalmol 1968;80: 606-17.

36. De Schryver A, Wachtmeister L, Båryd I. Ophthalmological observations on long-term survivors after radiotherapy for nasopharyngeal tumours. Acta Radiol Ther Phys Biol 1971;10:193-209. 
37. Shukovsky LJ, Fletcher GH. Retinal and optic nerve complications in a high dose irradiation technique of ethmoid sinus and nasal cavity. Radiology 1972;104:629-34.

38. Wara WH, Irvine AR, Neger RE, Howes EL, Phillips TL. Radiation retinopathy. Int J Radiat Oncol Biol Phys 1979; 5:81-4.

39. Bagan SM, Hollenhorst RW. Radiation retinopathy after irradiation of intracranial lesions. Am J Ophthalmol 1979; 88:694-7.

40. Morita K, Kawabe Y. Late effects on the eye of conformation radiotherapy for carcinoma of the paranasal sinuses and nasal cavity. Radiology 1979;130:227-32.

41. Tomsak RL, Smith JL. Radiation retinopathy in a patient with lung carcinoma metastatic to brain. Ann Ophthalmol 1980;12:619-22.

42. Thompson GM, Migdal CS, Whittle RJM. Radiation retinopathy following treatment of posterior nasal space carcinoma. Br J Ophthalmol 1983;67:609-14.

43. Kinyoun JL, Kalina RE, Brower SA, Mills RP, Johnson RH. Radiation retinopathy after orbital irradiation for Graves' ophthalmopathy. Arch Ophthalmol 1984;102: 1473-6.

44. Amoaku WMK, Archer DB. Cephalic radiation and retinal vasculopathy. Eye 1990;4:195-203.

45. Amoaku WMK, Archer DB. Fluorescein angiographic features, natural course and treatment of radiation retinopathy. Eye 1990;4:657-67.

46. Noble KG, Kupersmith MJ. Retinal vascular remodelling in radiation retinopathy. Br J Ophthalmol 1984;68:475-8.

47. Albert DM, Walton DS, Weichselbaum RR, Cassady JR, Little JB, Leumbruno D, et al. Fibroblast radiosensitivity and intraocular fibroblastic proliferation following radiotherapy for bilateral retinoblastoma. $\mathrm{Br} \mathrm{J}$ Ophthalmol 1986;70:336-42.

48. Archer DB, Amoaku WMK, Kelly G. Choroidoretinal neovascularisation following radon seed treatment of retinoblastoma in two patients. Br J Ophthalmol 1993;77:95-9.

49. Boozalis GT, Schachat AP, Green WR. Subretinal neovascularization from the retina in radiation retinopathy. Retina 1987;7:156-61.

50. Kinyoun JL, Chittum ME, Wells CG. Photocoagulation treatment of radiation retinopathy. Am J Ophthalmol 1988; 105:470-8.

51. Axer-Siegel R, Kremer I, Ben-Sira I, Weiss J. Radiation retinopathy treated with the krypton red laser. Ann Ophthalmol 1989;21:272-4.

52. Chaudhuri PR, Austin DJ, Rosenthal AR. Treatment of radiation retinopathy. Br J Ophthalmol 1981;65:623-5.

53. Parson JT, Fitzgerald CR, Hood CI, Ellingwood KE, Bova FJ, Million RR. The effects of irradiation on the eye and optic nerve. Int J Radiat Oncol Biol Phys 1983;9:609-22.

54. Monge OR, Flage T, Hatlevoll R, Vermund H. Sight saving therapy in retinoblastoma: experience with external megavoltage therapy. Acta Ophthalmol (Copenh) 1986;64: 414-20.

55. Buzney SM, Pruett RC, Regan CDJ, Walton DS, Smith TR. Scleral buckling for retinal detachment in patients with retinoblastoma. Am J Ophthalmol 1984;98:473-7.

56. MacFaul PA, Bedford MA. Ocular complications after therapeutic irradiation. Br J Ophthalmol 1970;54:237-47.

57. MacFaul PA. Local radiotherapy in the treatment of malignant melanoma of the choroid. Trans Ophthalmol Soc UK 1977;97:421-7.

58. Bedford MA. The use and abuse of cobalt plaques in the treatment of choroidal malignant melanomata. Trans Ophthalmol Soc UK 1973;93:139-43.

59. Foerster MH, Fried M, Wessing A, Meyer-Schwickerath G. Strahlenretinopathie nach Behandlung von Aderhautmelanomen mit ${ }^{106} \mathrm{Ru} /{ }^{106} \mathrm{Rh}$-applikatoren. Fortschr Ophthalmol 1983;80:418-21.
60. Packer S. Iodine-125 radiation of posterior uveal melanoma. Ophthalmology 1987;94:1621-6.

61. Char DH, Castro JR, Kroll S M, Irvine AR, Quivey JM, Stone RD. Five-year follow-up of helium ion therapy for uveal melanoma. Arch Ophthalmol 1990;108:209-14.

62. Merriam GR, Szechter A, Focht EF. The effects of ionizing radiations on the eye. Front Radiat Ther Oncol 1972;6: 346-85.

63. Nakissa N, Rubin P, Strohl R, Keys H. Ocular and orbital complications following radiation therapy of paranasal sinus malignancies and review of the literature. Cancer 1983;51:980-6.

64. Miller ML, Goldberg SH, Bullock JD. Radiation retinopathy after standard radiotherapy for thyroid-related ophthalmopathy. Am J Ophthalmol 1991;112:600-1.

65. Harris JR, Levene MB. Visual complications following irradiation for pituitary adenomas and craniopharyngiomas. Radiology 1976;120:167-71.

66. Aristizabal S, Caldwell WL, Avila J. The relationship of time-dose fractionation factors to complications in the treatment of pituitary tumours by irradiation. Int J Radiat Oncol Biol Phys 1977;2:667-73.

67. Berg NO, Lindgren M. Time-dose relationship and morphology of delayed radiation lesions of the brain in rabbits. Acta Radiol 1958;167(Suppl):1-77.

68. Char DH, Castro JR, Quivey JM, Chen GTY, Lyman JT, Stone RD, et al. Helium ion charged particle therapy for choroidal melanoma. Ophthalmology 1980;87:565-70.

69. Gragoudas ES, Goitein M, Verhey L, Munzenreider J, Suit HD, Koehler A. Proton beam irradiation: an alternative to enucleation for intraocular melanomas. Ophthalmology 1980;87:571-81.

70. Packer S, Rotman M. Radiotherapy of choroidal melanoma with iodine-125. Ophthalmology 1980;87:582-90.

71. Brown N, Roth J, Catterall M, Beal A. Effects of fast neutrons on the eye: a preliminary communication. Br J Ophthalmol 1975;59:510-13.

72. Roth J, Brown N, Catterall M, Beal A. Effects of fast neutrons on the eye. Br J Ophthalmol 1976;60;236-44.

73. Bessell EM, Henk JM, Whitelocke RAF, Wright JE. Ocular morbidity after radiotherapy of orbital and conjunctival lymphoma. Eye 1987;1:90-6.

74. Chan RC, Shukovsky LJ. Effects of irradiation on the eye. Radiology 1976;120:673-6.

75. Chacko DC. Considerations in the diagnosis of radiation injury. JAMA 1981;245:1255-8.

76. Spiel RT. Handbook of cancer chemotherapy. Boston, Mass: Little, Brown, 1976.

77. Portlock CS, Goffrett DR. Manual of clinical problems in oncology. Boston, Mass; Little, Brown, 1986.

78. Griffin JD, Garnick MB. Eye toxicity of cancer chemotherapy: a review of the literature. Cancer 1981;48: 1539-49.

79. Dhir SP, Joshi AV, Banerjee AK. Radiation retinopathy in diabetes mellitus: report of a case. Acta Radiol Oncol 1982;21:111-3.

80. Brown GC, Shields JA, Sanborn G, Augsburger JJ, Schatz NJ, Savino PJ. Radiation retinopathy. Trans Pa Acad Ophthalmol Otolaryngol 1981;34:144-51.

81. Brown GC, Shields JA, Sanborn G, Augsburger JJ, Savino PJ, Schatz NJ. Radiation optic neuropathy. Ophthalmology 1982;89:1489-93.

82. Karren KA, Kroll SM, Char DH, Castro JR. Diabetic radiation morbidity. Br J Ophthalmol 1992;76:61-2.

83. Archer DB, Amoaku WMK, Gardiner TA. Radiation retinopathy: clinical, histopathological, ultrastructural and experimental correlations. Eye 1991;5:239-51.

84. McQuaid M, Chakravarthy U, Archer DB. The effects of ionizing radiation on retinal microvascular cell growth in vitro. Doc Ophthalmol 1990;76(2):105-218. 
85. Andrews BS, McIntosh J, Petts V, Penny R. Circulating immune complexes in retinal vasculitis. Clin Exp Immunol 1977;29:23-9.

86. Standford MR. Retinopathy after irradiation and hyperbaric oxygen. J R Soc Med 1984;77:1041-3.

87. Schlaegel TF. Ocular histopathology of some Nagasaki atomic-bomb casualties. Am J Ophthalmol 1947;30: 127-35.

88. Dhermy P, Coscas G. Retinopathie par radiations et occlusion veineuse retienne (aspect histologique). Bull Soc Ophthal (Fr) Paris 1978;78:571-4.

89. Dumoulin-Wibail C, Toussaint D, Dumoulin P. Retinopathie par radiations ionisantes: aspects cliniques. Bull Soc Belge Ophthalmol 1982;199-200:43-53.

90. Koriyama S, Sakata H, Ogita S. Retinal lesions as a complication of radiotherapy. Jpn J Clin Ophthalmol 1976;30: 69-78.

91. Amoaku WMK. The effects of ionizing radiation on the retina: a clinical and experimental study. Thesis, Doctor of Philosophy, Queen's University of Belfast, 1990.

92. Cibis PA, Brown DVL. Retinal changes following ionizing radiation. Am J Ophthalmol 1955;40:84-8.

93. Cibis PA, Noell WK, Eichel B. Ocular effects produced by high intensity X-radiation. Arch Ophthalmol 1955;53: 651-63.

94. Brown DVL, Cibis PA, Pickering JE. Radiation studies on the monkey eye. I. Effects of gamma radiation on the retina. Arch Ophthalmol 1955;54:249-56.

95. Donegan J. Ocular effects of body ${ }^{60} \mathrm{Co}$ irradiation. Am J Ophthalmol 1956;42:309-10.

96. Newell FW, Choi O, Book NA, Harper PU, Simkus A. Focal ionizing radiation of the posterior ocular segment. Am J Ophthalmol 1960;50:1215-25.

97. Devi SK, Riley EF, Burns CA. Electroretinographic responses of the rabbit after X-irradiation. Invest Ophthalmol Vis Sci 1968;7:219-26.

98. Krohn DL, Jacobson JH, Na jac HW, Barsa Newton MC, Robertson JS. Toxic effect of thermal neutrons on the rabbit electro-retinogram. Am J Ophthalmol 1970;70:814-21.

99. Bonney CH, Schmidt RE, Hunter DM, Conley GE. Fluorescein angiography and light microscopy studies of retinae irradiated by oxygen nuclei. Aviat Space Environ Med 1977;48:418-23.

100. Gragoudas ES, Zakou NZ, Albert DM, Constable IJ: Longterm observations of proton-irradiated monkey eyes. Arch Ophthalmol 1979;97:2184-91.

101. Schmidt RE, Bonney CH. Oxygen nuclei irradiation of retinas: long-term observations. Radiat Res 1981;85: 355-66.

102. Newton JC, Barsa Newton MC, Wisniewski HM, Wen GY. Effects of X-radiation on the retina of the albino rabbit as viewed with the transmission electron microscope. Exp Cell Biol 1984;52:269-78.

103. Ching SV, Gillette SM, Powers BE, Roberts SM, Gilette EL, Withrow SJ. Radiation-induced ocular injury in the dog: a histological study. Int J Radiat Oncol Biol Phys 1990;19:321-8.

104. Irvine AR, Alvarado JA, Wara WM, Morris BW, Wood IS. Radiation retinopathy: an experimental model for the ischaemic-proliferative retinopathies. Trans Am Ophthalmol Soc 1981;79:103-22.

105. Irvine AR, Wood IS. Radiation retinopathy as an experimental model for ischemic proliferative retinopathy and rubeosis iridis. Am J Ophthalmol 1987; 103:790-7.
106. Amoaku WMK, Mahon GJ, Gardiner TA, Frew L, Archer DB. Late ultrastructural changes in the retina of the rat following low-dose X-irradiation. Graefes Arch Clin Exp Ophthalmol 1992;230:569-74.

107. Miller H, Miller B, Ishibashi T, Ryan SJ. Pathogenesis of laser-induced choroidal subretinal neovascularization. Invest Ophthalmol Vis Sci 1990;31:899-908.

108. Weber ML, Manclini MA, Frank RN. Retinovitreal neovascularization in the Royal College of Surgeons rat. Curr Eye Res 1989;8:61-74.

109. Sugita G, Tano Y, Machemer R. Experimental neovascularization of the retina. Int Ophthalmol 1980;2:33-7.

110. Degowin RL, Lewis LJ, Mason RE, Borke MK, Hoak JC. Radiation-induced inhibition of human endothelial cells replicating in culture. Radiat Res 1976;68:244-50.

111. Hall EJ. Radiobiology for the radiologist. Philadelphia: JB Lippincott, 1988:1-16.

112. Powell S, McMillen TJ. DNA damage and repair following treatment with ionizing radiation. Radiother Oncol 1990; 19:95-108.

113. Wheeler K, Wierowski J. DNA accessibility: a determinant of mammalian cell differentiation. Radiat Res 1983;93: 312-18.

114. Amoaku WMK, Frew L, Mahon GJ, Gardiner TA, Archer DB. Early ultrastructural changes after low-dose X-irradiation in the retina of the rat. Eye 1989;3:638-46.

115. Sinclair WK. Cyclic X-ray responses in mammalian cells in vitro. Radiat Res 1968;33:620-43.

116. Patil MS, Locher SE, Harihan PV. Radiation-induced thymine base damage and its excision repair in active and inactive chromatin of HeLa cells. Int J Radiat Biol 1985; 48:691-700.

117. Warters RL, Childers TT. Radiation-induced thymine base damage in replicating chromatin. Radiat Res 1982;90: 564-74.

118. Chiu SM, Oleinick NL, Friedman LR, Stambrook PJ. Hypersensitivity of DNA in transcriptionally active chromatin to ionizing radiation. Biochim Biophys Acta 1982; 699:15-21.

119. Winans LF, Dewey WC, Dettor CM. Repair of sublethal and potentially lethal X-ray damage in synchronous Chinese hamster cells. Radiat Res 1972;52:333-51.

120. Oleinick NL, Chiu SM, Friedman LR. Gamma radiation as a probe of chromatin structures: damage to and repair of active chromatin in the metaphase chromosome. Radiat Res 1984;98:629-41.

121. Zermeno A, Cole A. Radiosensitive structure of metaphase and interphase hamster cells as studied by low-voltage electron beam irradiation. Radiat Res 1969;39:669-84.

122. Datta R, Cole A, Robinson S. Use of track-end alpha particles from ${ }^{241} \mathrm{Am}$ to study radiosensitive sites in $\mathrm{CHO}$ cells. Radiat Res 1976;65:139-51.

123. Engerman RL, Pfaffenbach D, Davis MD. Cell turnover of capillaries. Lab Invest 1967;17:738-43.

124. Sharma NK, Gardiner TA, Archer DB. A morphological and autoradiographic study of cell death and regeneration in the retinal microvasculature of normal and diabetic rats. Am J Ophthalmol 1985;100:51-60.

125. Reinhold HS. The influence of radiation on blood vessels and circulation: cell viability of the vessel wall. In: Current topics in radiation research quarterly. Amsterdam: NorthHolland, 1974:9-28. 